Klaudia KAŁĄŻNA

Uniwersytet im. Adama Mickiewicza, Poznań

\title{
Pozycja kobiet na polskim rynku pracy. Uwarunkowania prawne i rzeczywistość
}

$\mathrm{T}$ ransformacja w Polsce przyniosła wiele zmian w zakresie rynku pracy, m.in. wzrost bezrobocia, które stało się jednym z największych społecznych problemów. Należy podkreślić, że w komunistycznych gospodarkach zagadnienie bezrobocia prawie nie istniało: wszyscy zdolni do pracy ją mieli, tzn. mieli obowiązek pracować. Ludzie żyjący w gospodarkach centralnie planowanych posiadali zakorzenione przekonanie, że zawsze znajdą pracę, że mogą zmienić ją tylko w poszukiwaniu lepszych zarobków, albo bardziej przyjaznej atmosfery (a nie z konieczności). Nowa sytuacja ekonomiczna postawiła ich w trudnym położeniu - wielu nie potrafiło się odnaleźć w rzeczywistości, w której każda para rąk nie była już niezbędna. Nagłe obniżenie poziomu życia spowodowało bezradność i frustrację wielu grup społecznych. Owa frustracja była następstwem tego, że społeczeństwo przed przemianami mitologizowało kapitalizm, dostrzegało tylko jego dobre strony, wyczekiwało z niecierpliwością na poprawę swej sytuacji. Zapominało o tym, że podczas transformacji nieuniknione są zmiany i wyrzeczenia, z trudem przyszło mu wyzbycie się roszczeniowych postaw. Jadwiga Mizieńska ujęła to zjawisko w metaforyczny sposób: „Niebezpieczeństwo «oczarowania widmem kapitalizmu» sprowadza się ostatecznie do tego, że z podziwem i zazdrością patrzymy na jego dojrzałe owoce, beztrosko zapominając, że wpierw trzeba było nawieźć i uprawić ziemie, posiać ziarno, wytrwale i skrupulatnie je pielęgnować, plewić chwasty, na odległy czas odkładając zbieranie i spożywanie plonów"1.

W ciagu dwóch lat transformacji zatrudnienie w Polsce zmniejszyło się o 1946 tys. osób, a równocześnie przyrastała liczba bezrobotnych: średniorocznie o ponad $1 \mathrm{mln}$ osób (w 1991 roku bez pracy pozostawało

1 Przedmowa J. Mizińskiej do rozprawy: M. Weber, Etyka protestancka a duch kapitalizmu, Lublin 1994, s. 12. 
2156 tys., czyli 11,4\% wszystkich zasobów siły roboczej) $)^{2}$. W gospodarkach nakazowo-rozdzielczych to państwo było pracodawcą, organizowało ono nawet prywatne życie obywateli, otaczało ich socjalnym bezpieczeństwem. Problemy regionu Europy Środkowej i Wschodniej związane z wysokim odsetkiem bezrobocia są zatem następstwem wieloletniego lansowania modelu pełnego zatrudnienia, nazywanego także stanem równowagi na rynku pracy. Pierwszy okres transformacji zaowocował szczególnym spadkiem stopy zatrudnienia, ale również w drugiej połowie lat 90. i na początku roku 2000, zaobserwować można negatywne tendencje. Analitycy rynku pracy zauważają, że w Polsce mimo wzrostu gospodarczego nie zmniejsza się liczba bezrobotnych. Zjawisko to określa się mianem jobless growth, czyli wzrost bezzatrudnieniowy.

Obecnie na rynkach pracy w krajach postkomunistycznych przeważającą grupą wśród bezrobotnych są kobiety. Ważnymi czynnikami wpływającymi na aktywność zawodową kobiet jest prowadzona przez państwo polityka dotycząca rodziny, rozwój instytucji opiekuńczych, czy pomoc materialna dla matek. W badaniach dotyczących sytuacji kobiet na polskim rynku pracy respondentki oceniają go zazwyczaj jako główną arenę nierówności, podkreślą brak poczucia bezpieczeństwa socjalnego, czasami z ich wypowiedzi przebija tęsknota za okresem PRL-u i stabilnością, jaką system ten zapewniał, promując powszechność zatrudnienia. Jednak należy zwrócić uwagę, na charakter owej „powszechności”. Realny socjalizm co prawda tworzył ,[...] żłobki, przedszkola, świetlice. A poza tym, realny socjalizm był systemem niedoboru wszystkiego, a więc i pracy. Brak rąk roboczych, przy niskich przeważnie płacach, prowadził do powszechnego zatrudniania kobiet. Było to połączone z odpowiednią propaganda, która korespondowała z powszechną w całej cywilizacji dążnością do emancypacji kobiet. Realny socjalizm zaczął w niej przodować. U wielu kobiet taka polityka rozbudzała ambicje i zaspokajała aspiracje, choć i wtedy kobiety miały utrudniony dostęp do kierowniczych stanowisk i niższe od mężczyzn wynagrodzenie za taką samą pracę. Zresztą praca w dużym stopniu przestawała być taka sama, bo dziedziny, które szczególnie marniały płacowo, jednocześnie feminizowały się [...]"3.

2 Dane na podst.: St. Socha-Sachalin, Transformacja rynku pracy, Koszalin 1998, s. $83-84$.

3 E. Skalski, Feminizm: krzyk czy rozmowa. Chłopcy wcale na to nie licza, „Rzeczpospolita”, z dnia 28.04.2002. 
Należy zauważyć, że współczesne kobiety są postawione przed wyborem: kariera zawodowa albo udane życie rodzinne. Przełamują co prawda narzucane im tradycją ograniczenia, wzrasta odsetek kobiet wykształconych, ale w naszych realiach często sukces w pracy równa się przesunięciu momentu zawarcia związku małżeńskiego i urodzenia dzieci. Kobiety wiedza, że moga przełamywać bariery na rynku pracy łatwiej niż w poprzednim systemie, jednak mają poczucie, że robią to kosztem wielu innych ważnych spraw, dlatego nie zawsze „opłaca się” działać wbrew stereotypom. $Z$ jednej strony pragną być doceniane i samodzielne, $z$ drugiej owo równouprawnienie zmusza je do rezygnacji z odgrywania ról przypisywanych dotychczas kobiecie. Badania prof. Henryka Domańskiego dowiodły, że wraz ze wzrostem liczby wykształconych kobiet wzrasta liczba kobiet niezamężnych. Podobnie w innych krajach, np. w Japonii: w 1985 roku wprowadzono równouprawnienie kobiet, co spowodowało dwukrotny wzrost liczby samotnych kobiet ${ }^{4}$. Należy podkreślić, że w wielu przypadkach nie są to kobiety samotne z wyboru: stawiając na swój sukces miały mniej czasu na relacje damsko-męskie, przełamując kolejne bariery np. awansu, wzbudzają strach wśród mężczyzn i są postrzegane przez nich jako mniej kobiece. Amerykańska socjolog - Jessie Bernard - twierdzi, że „mężczyźni poślubiają najchętniej kobiety, które są od nich młodsze, gorzej wykształcone i mają gorszy zawód"5. Według badań CBOS-u większym poważaniem cieszą się w społeczeństwie kobiety pracujące. Jednak tylko 37\% (a 60\% kobiet) mężczyzn wskazało, że bardziej szanują aktywne zawodowo kobiety, a ponad połowa z nich uważa, że nie ma to znaczenia. Zróżnicowanie płciowe nie występuje jedynie przy odpowiedziach: trudno powiedzieć i gospodyni domowa (po 4\% kobiet i 5\% mężczyzn). Jednocześnie tylko $24 \%$ mężczyzn uważa, że kobieta na kierowniczym stanowisku zyskuje na kobiecości, a 58\% uważa, że nie ma to wpływu na jej kobiecość. Tylko 9\% mężczyzn uważa, że kobieta-szef traci cechy kobiece. Można stwierdzić, że polscy mężczyźni coraz bardziej cenią zaangażowanie zawodowe kobiet, ale ponad połowie jest to zupełnie obojętne. W porównaniu z początkiem lat 90 -tych w społeczeństwie wzrosła liczba osób uważających, że praca zawodowa podnosi wartość kobiety, a większość kobiet uważa, że prestiż zapewnia im praca zawodowa, a nie poświęcanie się rodzinie i domowi.

4 Zob. I. Dominik, Wykształcona szuka męża, „Newsweek”, nr 31, 07.08.2005.

5 Ibidem. 
Wykres 1. Wyniki ankiety na temat aktywności zawodowej kobiet

Jak Pan(i) myśli, czy w naszym społeczeństwie jest bardziej szanowana:

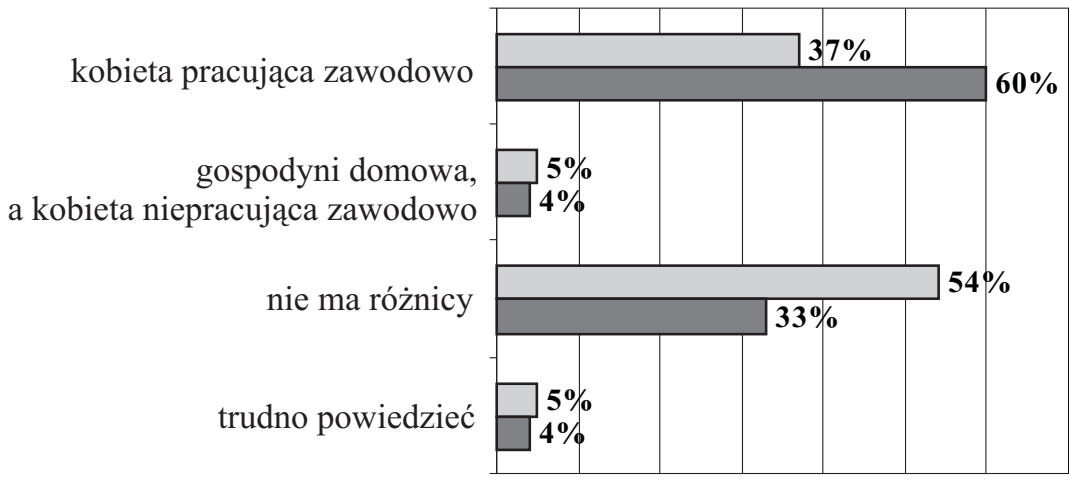

\section{odpowiedzi mężczyzn $\square$ odpowiedzi kobiet}

Źródło: CBOS, Komunikat z badań: Opinie o kobietach pracujacych zawodowo, Warszawa, 2003, Komunikat nr 2971, www.cbos.pl.

Warto zdefiniować w tym miejscu pojęcie dyskryminacji. Słowo pochodzi od łacińskiego dicriminatio - rozróżnienie, rozdzielenie. Oznacza „pozbawianie równouprawnienia, upośledzanie, szykanowanie pewnej grupy ludzi ze względu na ich pochodzenie, przynależność klasową, narodową, rasową i płeć” ${ }^{6}$. Nie ma powszechnie przyjętej definicji równości traktowania, określa się, że jest to „przekrojowa formuła penetrująca obszary swobody umów, działań faktycznych i zbiorowych praw, która nakazuje jednakowe traktowanie kobiet i mężczyzn, z której wywodzi się indywidualne, podmiotowe prawo każdej osoby do tego, by była jednakowo traktowana w pracy",

Jeżeli chodzi o uwarunkowania prawne, to równość kobiet i mężczyzn gwarantuje Konstytucja RP z 1997 roku. Artykuł 32 Konstytucji podkreśla równość wszystkich wobec prawa oraz zawiera zakaz dyskryminacji

${ }^{6}$ H. Jahns, Pozycja kobiety na europejskim rynku pracy, „Wspólnoty Europejskie" 1998, nr 5.

7 Ibidem. 
w różnych sferach życia: politycznej, społecznej, gospodarczej ${ }^{8}$. Następny artykuł stanowi, że: Kobieta i mężczyzna mają równe prawa w życiu rodzinnym, politycznym, społecznym i gospodarczym (art. 33.1.), oraz że kobieta i mężczyzna mają w szczególności równe prawo do kształcenia, zatrudnienia i awansów, do jednakowego wynagradzania za pracę jednakowej wartości, do zabezpieczenia społecznego oraz zajmowania stanowisk, pełnienia funkcji oraz uzyskiwania godności publicznych i odznaczeń (art. 33.2.). Natomiast w prawie pracy, nowelą Kodeksu pracy z 1996 roku ${ }^{9}$ wprowadzono zasadę równości kobiet i mężczyzn (art. $11^{2}$ ). Pracownicy mają równe prawa $z$ tytułu jednakowego wypełniania takich samych obowiązków; dotyczy to $\mathrm{w}$ szczególności równego traktowania mężczyzn i kobiet w dziedzinie pracy) oraz zakaz jakiejkolwiek dyskryminacji w stosunkach pracy - na pierwszym miejscu (obok niepełnosprawności, rasy, narodowości, przekonań politycznych i religijnych, przynależności związkowej) wymieniono płeć (art. $11^{3}$ ). Ponadto zaznaczono, że pracodawca jest obowiązany szanować godność i inne dobra osobiste pracownika (art. $11^{1}$ ). Dalsze zmiany, które wynikały m.in. z potrzeby dostosowania naszego ustawodawstwa do wymogów Unii Europejskiej zostały wprowadzone nowelizacją z 2003 roku $^{10}$. Zmieniono art. $11^{3}$ poprzez dodanie cech (wiek, pochodzenie etniczne, wyznanie, orientacja seksualna, zatrudnienie na czas określony lub nieokreślony, zatrudnienie w pełnym lub niepełnym wymiarze czasu pracy), z powodu których nie jest dopuszczalna dyskryminacja. Artykuł $18^{3 a}$ definiuje równe traktowanie w zatrudnieniu jako niedyskryminowanie w jakikolwiek sposób. W artykule tym rozróżniono dyskryminację pośrednią i bezpośrednią. Jeżeli odnieść owo rozróżnienie do płci, to z dyskryminacją bezpośrednią mamy do czynienia, kiedy pracownik z powodu przynależności do danej płci jest lub mógłby być traktowany mniej korzystnie. Natomiast dyskryminacja pośrednia występuje, gdy na skutek pozornie neutralnego postanowienia, zastosowanego kryterium lub podjętego działania występują dysproporcje w zakresie warunków zatrudnienia na niekorzyść wszyst-

8 Art. 32.1. Wszyscy są wobec prawa równi. Wszyscy mają prawo do równego traktowania przez władze publiczne. Art. 32.2. Nikt nie może być dyskryminowany w życiu politycznym, społecznym lub gospodarczym z jakiejkolwiek przyczyny. Konstytucja Rzeczypospolitej Polskiej z dnia 2 kwietnia 1997 roku, Dz. U. 1997, Nr 78, poz. 48.

9 Dz. U. 1996, Nr 24, poz. 110.

10 Dz. U. 2003, Nr 213, poz. 2081. 
kich lub znacznej liczby pracowników należących danej płci, jeżeli dysproporcje te nie mogą być uzasadnione innymi obiektywnymi powodami. Poza tym artykuł $18^{3 a}$ odnosi się już nie tylko do warunków zatrudnienia, ale również do nawiązania i rozwiązania stosunku pracy, awansowania oraz dostępu do szkolenia w celu podnoszenia kwalifikacji zawodowych. Jeżeli chodzi o dyskryminację ze względu na płeć, to rozszerzono jej definicję, precyzując pojęcie molestowania seksualnego, jako jednego z przejawów takiej dyskryminacji. Molestowanie seksualne zdefiniowano jako każde nieakceptowane zachowanie o charakterze seksualnym lub odnoszące się do płci pracownika, którego celem lub skutkiem jest naruszenie godności lub poniżenie albo upokorzenie pracownika. Zachowanie to może się składać z następujących elementów:

- elementy fizyczne (np. poklepywanie, dotykanie, przytulanie),

- elementy werbalne (np. obraźliwe słowa, wulgarne wypowiedzi, składanie niewłaściwych propozycji),

- elementy pozawerbalne (np. gesty, miny czy spojrzenia sugerujące pożądanie).

Pracownik może dochodzić odszkodowania z tytułu dyskryminacji. „Na mocy art. 94 pkt. 2b k.p. nałożono na pracodawcę obowiązek przeciwdziałania dyskryminacji w zatrudnieniu. Uregulowanie to statuuje pracodawcę w roli podmiotu zapobiegającego dyskryminacji i zwalczającego jej przejawy. [...] w wypadku zachowania przez pracodawcę biernej postawy wobec aktów dyskryminacji w zatrudnieniu (np. poniżania, molestowania itp.) dyskryminowany pracownik może na podstawie art. $55^{1}$ par. 1 k.p. rozwiązać umowę o pracę bez wypowiedzenia i docho-

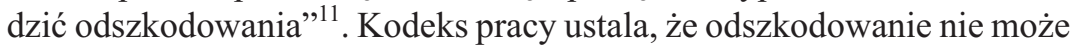
być niższe, niż najniższe wynagrodzenie za pracę, a w wyniku nowelizacji art. $18^{\mathrm{d}}$ (styczeń 2004 r.) zniesiono górną granicę odszkodowania. Obecnie zwraca się uwage, na konieczność wprowadzenia w prawie pracy zmian odnoszących się do mobbingu i molestowania seksualnego. Środowisko prawnicze na konferencji zorganizowanej przez Institute for International Research przedstawiło propozycję wprowadzenia rzecznika praw pracowniczych w przedsiębiorstwach ${ }^{12}$. Chodzi o wyeliminowanie takich patologicznych sytuacji jak ta, kiedy kobieta zażądała od pracodawcy od-

11 R. Babińska, Odszkodowanie za dyskryminację, „Prawo Pracy”, „Gazeta Prawna" z dnia 13.12.2004 r.

${ }^{12}$ R. Majewska, Rzecznik od molestowania, „Prawo co dnia”, „Rzeczpospolita” $\mathrm{z}$ dnia $21.10 .2005 \mathrm{r}$. 
szkodowania w wysokości $5 \mathrm{mln}$ zł z powodu molestowania jej przez kolegę w biurze. Gdyby wprowadzono zmiany postulowane m.in. przez sędziego Zbigniewa Szczukę, poszkodowany najpierw musiałby zwrócić się do wspomnianego rzecznika, a potem dopiero wnosić pozew.

Polska uznaje także międzynarodowe regulacje dotyczące niedyskryminacji i równości płci. System Narodów Zjednoczonych posługuje się pojęciem uwłasnowolnienia kobiet (ang. empowerment), czyli wzmocnieniem ich pozycji. Sekretarz generalny ONZ w Nowym Jorku w 2005 roku powiedział: „Sześćdziesiąt lat minęło od czasu, gdy założyciele Organizacji Narodów Zjednoczonych zapisali równe prawa dla kobiet i mężczyzn na pierwszej stronie naszej Karty. Od tego czasu kolejne doświadczenia pokazały, że nie ma skuteczniejszego narzędzia rozwoju niż uwłasnowolnienie kobiet"13. W sprawie kobiet odbyły się cztery konferencje (Meksyk - 1975 r., Kopenhaga - 1980 r., Nairobi - 1985 r. i Pekin 1995 r.). Rok 1975 proklamowano międzynarodowym rokiem kobiet, natomiast lata 1976-1985 Dekadą ONZ na rzecz kobiet. Ostatnia z konferencji - Konferencja w Pekinie - przyjęła dokument końcowy zwany Platformą Działania. Wymieniono w niej 12 obszarów, w których należy podjąć działania, by walczyć z dyskryminacją kobiet. W odniesieniu do zatrudnienia wydaje się najważniejszy obszar szósty, zatytułowany „Kobiety i gospodarka". Postuluje się w nim następujące działania ${ }^{14}$ :

- promować ekonomiczne prawa i niezależność kobiet, włączając w to dostęp do zatrudnienia, dogodne warunki pracy i kontrolę nad zasobami ekonomicznymi,

- ułatwić kobietom równy dostęp do zasobów, zatrudnienia, rynków i handlu,

- świadczyć usługi doradcze, organizować szkolenia i umożliwiać dostęp do rynków, technologii i informacji, zwłaszcza dla kobiet o niższych dochodach,

- wzmacniać zdolność ekonomiczną kobiet i sieci handlowych,

- eliminować segregację w zatrudnieniu i wszelkie formy dyskryminacji w zatrudnieniu.

13 Przemówienie Koffiego Annana na otwarciu Sesji Komisji ds. Statusu Kobiet, Nowy Jork, 28.02.2005 r., http://www.unic.un.org.pl/kobiety_rozwoj_pokoj/konferencja.php.

14 Na podstawie informacji ze strony: http://www.unic.un.org.pl/rownouprawnienie/platforma_dzialania.php. Dokument opracowany przez Ośrodek Informacji ONZ w Warszawie na podst. materiałów ONZ, kwiecień 2003 r. 
Dokumentem nazywanym Konstytucją Kobiet jest Konwencja w sprawie likwidacji wszelkich form dyskryminacji kobiet z 1979 roku $^{15}$. Po raz pierwszy zdefiniowano w niej dyskryminację wobec kobiet (w art. 1), która oznacza: wszelkie zróżnicowanie, wyłączenie lub ograniczenie ze względu na płeć, które powoduje lub ma na celu uszczuplenie albo uniemożliwienie kobietom, niezależnie od ich stanu cywilnego, przyznania, realizacji bądź korzystania na równi z mężczyznami z praw człowieka oraz podstawowych wolności w dziedzinach życia politycznego, gospodarczego, społecznego, kulturalnego, obywatelskiego i innych. W tej konwencji dopuszczono również tzw. dyskryminację pozytywna (art. 4), która pozwala na uprzywilejowanie jednej z płci w celu doprowadzenia do przyspieszenia osiąnnięcia równości między kobietami i mężczyznami. Po osiągnięciu równości należy zrezygnować z narzędzi dyskryminacji pozytywnej. Zaznaczono także, że udogodnienia wprowadzane przez Państwa w związku z ochroną macierzyństwa nie są uważane za dyskryminację. W 1999 roku został przyjęty Protokół fakultatywny ${ }^{16}$ do tej konwencji. Na jego mocy kobiety mogą składać skargi do Komitetu do Spraw Likwidacji Dyskryminacji Kobiet.

Również Międzynarodowa Organizacja Pracy przyjęła konwencje w których porusza zagadnienie równości płci. Szczególna uwaga należy się dwóm: konwencji nr 111, dotyczącej dyskryminacji w zakresie zatrudnienia i wykonywania zawodu, przyjętej w 1958 r. oraz konwencji nr 110 dotyczącej jednakowego wynagrodzenia dla pracujących mężczyzn i kobiet za pracę jednakowej wartości uchwalonej w 1951 roku $^{17}$. W konwencji nr 111 wyjaśniono pojęcie dyskryminacji, która oznacza (art. 1):

a) wszelkie rozróżnienie, wyłączenie lub uprzywilejowanie oparte na rasie, kolorze skóry, płci, religii, poglądach politycznych, pochodzeniu narodowym lub społecznym, które powoduje zniweczenie albo naruszenie równości szans lub traktowania w zakresie zatrudnienia lub wykonywania zawodu;

b) wszelkie inne rozróżnienie, wyłączenie lub uprzywilejowanie powodujące zniweczenie albo naruszenie równości szans lub traktowania

15 Angielski tekst konwencji: http:/www.un.org/womenwatch/daw/cedaw/text/econvention.htm, polski przekład urzędowy: Dz. U. 1982, Nr 10, poz. 71.

16 Dz. U. 2004, Nr 248, poz. 2484.

17 Teksty konwencji na polskich stronach Międzynarodowej Organizacji Pracy: http://www.mop.pl/doc/html/konwencje/k100.html oraz http://www.mop.pl/doc/html/konwencje/k111.html. 
w zakresie zatrudnienia lub wykonywania zawodu, które będzie mogło być wymienione przez zainteresowanego Członka po zasięgnięciu opinii reprezentatywnych organizacji pracodawców i pracowników, o ile takie istnieją, oraz innych właściwych organizacji.

Natomiast konwencja nr $100 \mathrm{w}$ artykule $1 \mathrm{~b}$ mówi o tym, że wyrażenie ,jednakowe wynagrodzenie dla pracujących mężczyzn i kobiet za pracę jednakowej wartości” stosuje się do stawek wynagrodzenia, ustalonych bez dyskryminacji opartej na płci. Warto również wspomnieć o konwencji nr 156, która dotyczy równości szans i traktowania pracowników obu płci: pracowników mających obowiązki rodzinne.

Należy pamiętać, że pierwszy katalog praw człowieka ustaliła Powszechna Deklaracja praw człowieka (1948 r. $)^{18}$. Artykuł 23 Deklaracji mówi m.in. o prawie każdego człowieka do swobodnego wyboru pracy, do odpowiednich i zadowalających warunków pracy, do ochrony przed bezrobociem, do równej płacy za równą pracę, do odpowiedniego i zadowalającego wynagrodzenia oraz do tworzenia i przystępowania do związków zawodowych. O dyskryminacji traktują także dwa międzynarodowe dokumenty z 1966 roku, dotyczące praw człowieka: Międzynarodowy Pakt Praw Obywatelskich i Politycznych oraz Międzynarodowy Pakt Praw Gospodarczych, Społecznych i Kulturalnych. W obu Paktach (art. 3) znajduje się zobowiązanie do zapewnienia równości kobiet i mężczyzn w zakresie korzystania z praw obywatelskich i politycznych (Międzynarodowy Pakt Praw Obywatelskich i Politycznych) oraz gospodarczych, społecznych i kulturalnych (Międzynarodowy Pakt Praw Gospodarczych, Społecznych i Kulturalnych). Pierwszy z wymienionych aktów podkreśla, że wszyscy mają zagwarantowane prawo do ochrony prawnej i nie można nikogo w tym zakresie dyskryminować, m.in. ze względu na płeć ${ }^{19}$. Natomiast Międzynarodowy Pakt Praw Gospodarczych, Społecznych i Kulturalnych kładzie nacisk na równość w stosunkach pracy. Podkreśla się

$18 \mathrm{http}: / /$ www.unic.un.org.pl/prawa_czlowieka/dok_powszechna_deklaracja.php, tekst w języku polskim opracowany przez Ośrodek Informacji ONZ w Warszawie, na podstawie materiałów ONZ.

19 Wszyscy są równi wobec prawa i są uprawnieni bez żadnej dyskryminacji do jednakowej ochrony prawnej. Jakakolwiek dyskryminacja w tym zakresie powinna być ustawowo zakazana oraz powinna być zagwarantowana przez ustawę równa dla wszystkich i skuteczna ochrona przed dyskryminacją z takich względów jak: rasa, kolor skóry, płeć, język, religia, poglądy polityczne lub inne, pochodzenie narodowe lub społeczne, sytuacja majątkowa, urodzenie lub jakiekolwiek inne okoliczności (art. 26). Przekład urzędowy: Dz. U. 1977, Nr 38, poz. 167. 
w nim, że sprawiedliwe i korzystne warunki pracy obejmują w szczególności (art. 7):

a) wynagrodzenie zapewniające wszystkim pracującym jako minimum:

i) godziwy zarobek i równe wynagrodzenie za pracę o równej wartości bez jakiejkolwiek różnicy; w szczególności należy zagwarantować kobietom warunki pracy nie gorsze od tych, z jakich korzystają mężczyźni, oraz równą płacę za równą pracę,

ii) zadowalające warunki życia dla nich samych i ich rodzin zgodnie z postanowieniami niniejszego Paktu,

b) warunki pracy odpowiadające wymaganiom bezpieczeństwa i higieny,

c) równe dla wszystkich możliwości awansu w pracy na odpowiednio wyższe stanowisko w oparciu jedynie o kryteria stażu pracy i kwalifikacji,

d) wypoczynek, wolny czas i rozsądne ograniczenie czasu pracy, okresowe płatne urlopy oraz wynagrodzenie za dni świąteczne ${ }^{20}$.

Polska jako członek Unii Europejskiej powinna dostosować swoje przepisy do prawa wspólnotowego, dlatego istotne wydaje się przybliżenie uregulowań w zakresie równouprawnienia kobiet i mężczyzn. Regulacje takie są zawarte zarówno w traktatach, jak i w prawie wtórnym. Już w Traktatach Rzymskich z $1958^{21}$ roku poświęcono artykuł 119 kwestii wynagrodzeń. Wprowadzono zasadę równości wynagrodzeń dla pracowników płci męskiej i żeńskiej za taką samą pracę. Traktat o Wspólnocie Europejskiej $^{22}$ w artykule 141 nawiązuje do Traktatów Rzymskich, ale rozciaga zasadę równości wynagrodzeń także na pracę tej samej wartości. Ponadto w TWE zaznacza się, że Rada może podjąć odpowiednie działania, by zapewnić stosowanie zasady równości szans i traktowania kobiet i mężczyzn w dziedzinie zatrudnienia i pracy. Bardziej szczegółowe uregulowania znajdują się w prawie wtórnym, a narzędziem, które wywiera szczególny wpływ na Państwa Członkowskie jest dyrektywa ${ }^{23}$. Dyrektywy wprowadzają następujące zasady:

- równego traktowania kobiet i mężczyzn przy ustalaniu kryteriów wynagradzania za równą pracę i pracę tej samej wartości, - równego dostępu do zatrudnienia, szkoleń i awansu,

20 Przekład urzędowy: Dz. U. 1977, Nr 38, poz. 169.

21 Traktaty rzymskie, Tekst po polsku: http:/www1.ukie.gov.pl/WWW/dok.nsf/ 0/16076599767A8A61C1256E83004B4BED?Open\&RestrictToCategory.

22 Traktat Ustanawiający Wspólnotę Europejską, (tekst skonsolidowany - wersja po Nicei). Tekst po polsku: http://www1.ukie.gov.pl/WWW/dok.nsf/0/ 16076599767A8A61C1256E83004B4BED?Open\&RestrictToCategory. 
- równego dostępu do ubezpieczeń społecznych,

- rozłożenia ciężaru dowodu w sytuacji dyskryminacji ze względu na płeć.

Bardzo ważne jest także Zalecenie Komisji 92/131/EWG w sprawie ochrony godności kobiet i mężczyzn w pracy), którego integralna część stanowi Kodeks postępowania w sprawie zwalczania molestowania seksualnego.

W najnowszym sprawozdaniu Komisji na temat równości płci, który opublikowano 14.02.2005 r. stwierdzono, że „Nie ma zbyt wielu dowodów świadczących o postępie w niwelowaniu różnicy w wynagrodzeniu kobiet i mężczyzn, która utrzymuje się na poziomie ok. 16\% w UE-15. Szacowana liczba dla 25 krajów UE jest nieco niższa, 15\%, przy uwzględnieniu różnic $\mathrm{w}$ wynagrodzeniu w nowych Państwach Członkowskich. Segregacja płciowa na rynku pracy wskazuje również na powolny postęp i pozostaje na wysokim poziomie zarówno w aspekcie zawodowym 10 (17,5\%), jak i sektorowym 11 (25,2\%). W 2003 r. kobiety zajmowały $31 \%$ stanowisk kierowniczych, w porównaniu z 30\% w 2002 r." 24 W punkcie sprawozdania zatytułowanym Wzmacnianie pozycji kobiet na rynku pracy Komisja zaapelowała m.in. $\mathrm{o}^{25}$ : osiaggnięcie $50 \%$ wskaźnika zatrudnienia starszych pracowników do roku 2010 (wskazano na dużą rozbieżność we wskaźniku zatrudnienia wśród starszych kobiet i mężczyzn), zajęcie się

23 Dyrektywa Rady 76/207/EWG w sprawie wprowadzania zasady równego traktowania mężczyzn i kobiet w zakresie dostępu do zatrudnienia, kształcenia i awansu zawodowego oraz warunków pracy, Dyrektywa Rady 86/613/EWG w sprawie stosowania zasady równego traktowania mężczyzn i kobiet pracujących na własny rachunek, w tym w rolnictwie, oraz w sprawie ochrony macierzyństwa, Dyrektywa Rady 75/117/EWG w sprawie zbliżania ustawodawstw Państw Członkowskich w zakresie stosowania zasady równego wynagradzania pracowników mężczyzn i kobiet, Dyrektywa Rady 97/80/WE dotycząca ciężaru dowodu w przypadkach dyskryminacji ze względu na płeć, Dyrektywa Rady 79/7/EWG dotycząca stopniowego wprowadzania zasady równego traktowania mężczyzn i kobiet w zakresie ubezpieczeń społecznych, Dyrektywa Rady nr 2004/113/WE z dnia 13 grudnia 2004 r. wprowadzająca w życie zasadę równego traktowania mężczyzn i kobiet w zakresie dostępu do towarów i usług oraz dostarczania towarów i usług, Dyrektywa Parlamentu Europejskiego i Rady 2002/73/WE zmieniająca dyrektywę Rady 76/207/EWG w sprawie wprowadzenia $\mathrm{w}$ życie zasady równego traktowania mężczyzn i kobiet w zakresie dostępu do zatrudnienia, kształcenia i awansu zawodowego oraz warunków pracy.

24 Sprawozdanie Komisji dla Rady, Parlamentu Europejskiego, Europejskiego Komitetu Ekonomiczno-Społecznego i Komitetu Regionów, na temat równości kobiet i mężczyzn, 2005 r., Bruksela dn. 14.02.2005 r., COM (2005) 44 końcowy s. 5.

25 Ibidem, s. 7. 
kwestią utrzymywania się dużych nierówności w wynagrodzeniu i segregacji płciowej na rynku pracy, zapewnienie równych szans na rynku pracy zarówno kobietom, jak i mężczyznom sprawującym opiekę nad dziećmi lub innymi osobami na ich utrzymaniu, zagwarantowanie wykorzystania środków z funduszy strukturalnych i z Europejskiego Funduszu Społecznego w celu zwalczenia stereotypów dotyczących płci w oświacie oraz na rynku pracy, oraz zmniejszania różnic w wynagrodzeniu kobiet i mężczyzn, zmodyfikowanie systemów emerytalnych, zlikwidowanie przeszkód o charakterze finansowym i niefinansowym w udziale kobiet w rynku pracy oraz powodujących długie przerwy w karierze zawodowej.

Kobiety w Polsce znacznie częściej dotyka problem bezrobocia niż mężczyzn. Stanowią większy odsetek bezrobotnych i trudno wrócić im do aktywności zawodowej - zasilają rzesze bezrobotnych długookresowo. Według danych BAEL za pierwszy kwartał 2005 roku stopa bezrobocia kobiet wynosiła 19,1\% natomiast mężczyzn - 17,2\%.

Tabela 1

Stopa bezrobocia w latach 1994-2005 na podstawie BAEL

\begin{tabular}{|c|c|c|}
\hline \multirow{2}{*}{ Lata } & Mężczýñni & Kobiety \\
\cline { 2 - 3 } & \multicolumn{2}{|c|}{ w\% } \\
\hline 1994 & 12,3 & 15,7 \\
\hline 1995 & 12,1 & 14,4 \\
\hline 1996 & 9,9 & 13,4 \\
\hline 1997 & 8,7 & 12,0 \\
\hline 1998 & 9,3 & 12,2 \\
\hline 1999 & 13,0 & 18,1 \\
\hline 2000 & 14,2 & 18,1 \\
\hline 2001 & 17,3 & 20,0 \\
\hline 2002 & 19,0 & 20,6 \\
\hline 2003 & 18,4 & 20,3 \\
\hline 2004 & 18,2 & 19,9 \\
\hline $2005^{\text {a }}$ & 17,2 & 19,1 \\
\hline
\end{tabular}

a - według danych za pierwszy kwartał 2005 roku

Źródło: GUS, Kobiety i mężczyźni na rynku pracy,

http://www.stat.gov.pl/dane_spol-gosp/praca_ludnosc/kob_mez_praca/index.htm, http://www.stat.gov.pl/opracowania_zbiorcze/maly_rocznik_stat/2005/05_ryn_pra.pdf,

http://www.stat.gov.pl/dane_spol-gosp/praca_ludnosc/kwart_inf_ryn_pracy/2005/II/tab3.pdf.

Od roku 1994 bezrobocie wśród kobiet malało (jak w całej zresztą populacji), aby od 1997 roku znowu stopniowo rosnąć i uzyskać na początku XXI wieku bardzo wysoki poziom: 19-20\%. 
Wykres 2. Stopa bezrobocia w latach 1994-2005 na podstawie BAEL

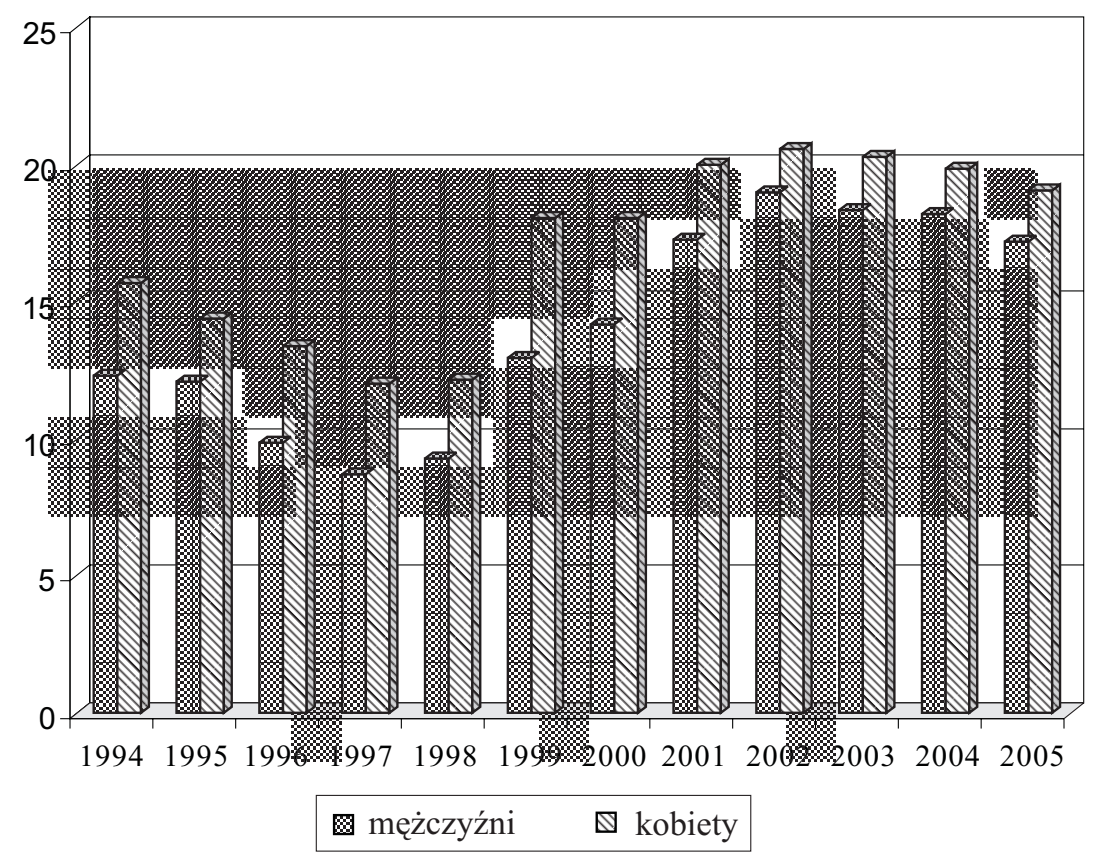

Źródło: Opracowanie własne, na podst. źródeł jak w tabeli 1.

Najwyższą stopę bezrobocia w 2003 roku można odnotować wśród kobiet w wieku 18-19 lat, natomiast najwięcej kobiet przypadało na mężczyzn w grupie bezrobotnych w wieku 30-44 lata. Autorzy raportu GUS piszą, że na 100 mężczyzn przypadało aż 112 kobiet, a stopa bezrobocia kobiet była o połowę wyższa niż mężczyzn W raporcie zaznacza się, że bezrobotne kobiety mają lepsze wykształcenie niż mężczyźni: ponad 50\% posiadało wykształcenie średnie lub wyższe, natomiast mężczyźni z analogicznym wykształceniem stanowili zaledwie $32 \%$.

Ponad połowa bezrobotnych płci żeńskiej pozostaje ponad rok bez pracy $-57,5 \%$. Z tego aż $41 \%$ to kobiety bezrobotne ponad dwa lata. Duża ilość kobiet pozostających długo bez zatrudnienia niepokoi tym bardziej, że ogólny poziom bezrobocia jest w Polsce wysoki, a tym samym ludzie po tak długim okresie niewykorzystywania swoich umiejętności w pracy są wypychani na margines rynku i bardzo trudno im znaleźć jakiekolwiek 
Wykres 3. Stopa bezrobocia według płci i wieku w 2003 r.

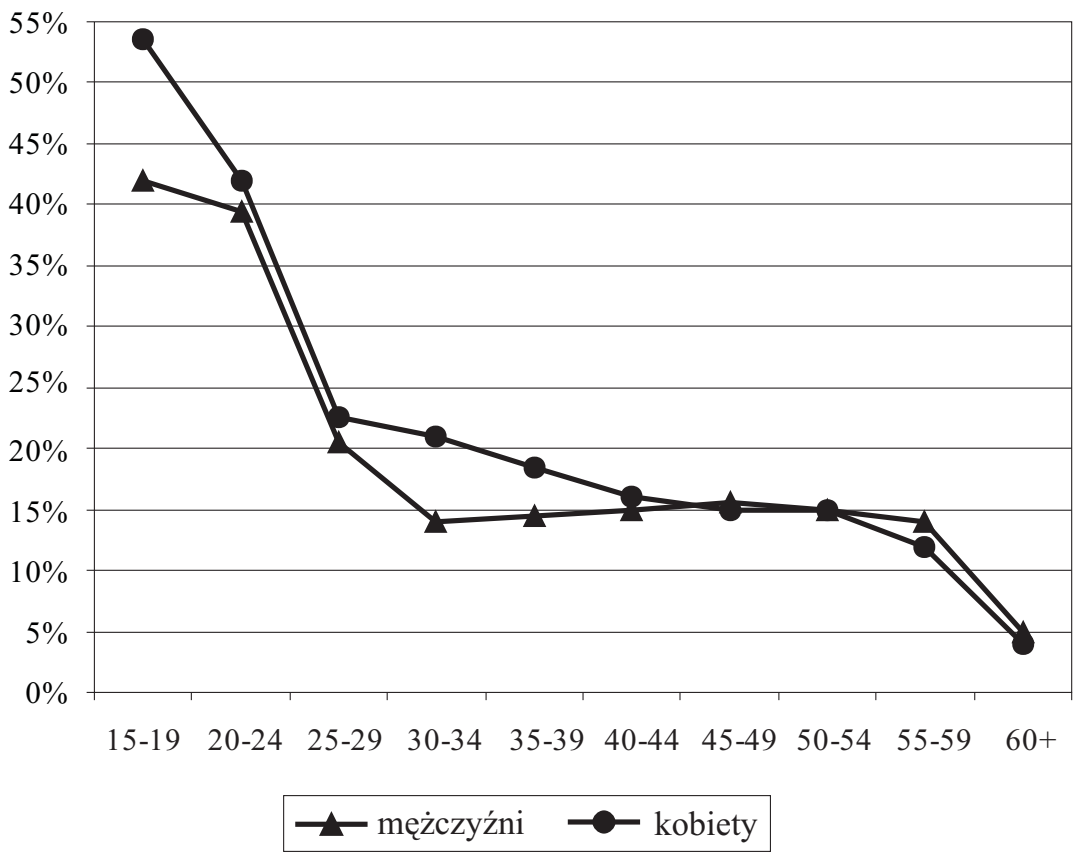

Źródło: GUS, Kobiety i mężczyźni na rynku pracy, http://www.stat.gov.pl/dane_spol-gosp/praca_ludnosc/kob_mez_praca/index.htm.

zatrudnienie. Osoby długo pozostające niezatrudnionymi stają się mniej atrakcyjne dla pracodawców, gdyż ich doświadczenie i kompetencje starzeją się.

Tabela 2

Bezrobotni zarejestrowani według czasu zatrudnienia w 2004 roku

\begin{tabular}{||l|c|c|c||}
\hline Czas pozostawania bez pracy & Ogólem & Mężczyźni & Kobiety \\
\hline 3 m-ce i mniej & 20,1 & 24,2 & 16,3 \\
\hline 3-6 m-cy & 12,2 & 12,6 & 11,8 \\
\hline 6-12 m-cy & 15,5 & 16,8 & 14,4 \\
\hline 12-24 m-cy & 17,0 & 17,7 & 16,4 \\
\hline Powyżej 24 m-cy & 35,2 & 28,7 & 41,1 \\
\hline
\end{tabular}

Źródło: Mały rocznik statystyczny 2005 - rynek pracy, http://www.stat.gov.pl/opracowania_zbiorcze/maly_rocznik_stat/2005/05_ryn_pra.pdf. 
Rozważając przyczyny znacznie gorszej pozycji kobiet względem mężczyzn na rynku pracy, należy wspomnieć o pojęciu seksizmu. Seksizm został po raz pierwszy zdefiniowany przez Faulkendera w 1985 roku. Istnieje wiele definicji tego zjawiska, najczęściej określa się je jako przekonanie o wyższości jednej płci nad drugą. Badania dowodzą, że kobiety są częściej dyskryminowane niż mężczyźni, aczkolwiek nie określa się tego wyraźnie w definicjach ${ }^{26}$. Z przejawami seksizmu można się spotkać we wszystkich wymiarach życia społecznego. Jeżeli chodzi o rynek pracy, to funkcjonują tutaj niestety stereotypy dotyczące płci oraz bariery awansu kobiet. Znacząco ograniczają one aktywność zawodową kobiet lub powodują, że nie mogą one odnieść sukcesu w tzw. „męskich” zawodach, mimo formalnego zakazu dyskryminacji ze względu na płeć i wielu działań podjętych na arenie międzynarodowej i w kraju. Pojęcie stereotypu, wprowadził Walter Lippman w wydanej w 1922 roku książce Public Opinion, gdzie pisał o obrazkach w głowie człowieka, które bardzo trudno zmienić, jeżeli się w niej pojawią. Psychologia społeczna określa stereotyp jako „generalizację odnoszącą się do grupy, w ramach której identyczne charakterystyki zostają przypisane wszystkim bez wyjątku jej członkom, niezależnie od rzeczywistych różnic między nimi" ${ }^{27}$. Stereotypy dotyczące płci na rynku pracy wynikają m.in. z przypisywania kobietom jednakowych cech: wg wielu pracodawców kobiety są bardziej uległe, można nimi łatwiej kierować, nie potrafią logicznie myśleć, są kłótliwe itp. Bardzo często uznaje się, że kobiety są mniej inteligentne od mężczyzn, a wiele ze swoich osiagnięć zawdzięczają tylko wytężonej pracy. Już w badaniu z 1984 roku $^{28}$ wykazano, że przedstawiciele obu płci są skłonni przyznać, że mężczyźni mniej wysiłku wkładają w osiągnięcie sukcesu niż kobiety. Studentki i studenci mieli ocenić osiągnięcia lekarki i lekarza - studenci twierdzili, że lekarka była mniej kompetentna niż lekarz i miała łatwą drogę do sukcesu, natomiast studentki sądziły, że musiała się więcej napracować niż lekarz, ale kompetentni byli według nich tak samo. Bardzo ważne jest spostrzeżenie, że przedstawiciele obu płci uważali, że kobieta lekarz miała większą motywację i dlatego osiagnnęła sukces.

26 A. Mikocka-Waluś, Seksizm a rola kobiety w społeczeństwie polskim, „Kobieta i biznes" 2004, nr 1-4.

27 E. Aronson, T. D. Wilson, R. M. Akert, Psychologia społeczna. Serce i umyst, Poznań 1997, s. 543.

28 Ibidem, s. 544. 
Należy zwrócić uwagę, że wiele stereotypów wynika z tradycji. Kobietom przypisuje się rolę opiekunki ogniska domowego i wychowawcy dzieci, osoby troszczącej się o wszystkich członków rodziny, przedkładającej szczęście bliskich nad swą karierę zawodową, pomija się fakt, że te dwie sprawy można ze sobą godzić. Już małym dziewczynkom nakazuje się bawić lalkami i w procesie socjalizacji przygotowuje się je do roli „pani domu”. „Nie tylko nie uciekamy przed taką dyskryminacją w naszych najbardziej intymnych związkach, lecz nie potrafimy ich sobie wyobrazić bez opartych na płci, wewnętrznie asymetrycznych relacji implikujących różnice statusu. Nie potrafimy zrobić kroku, nie zajmując pozycji określonych przez społeczeństwo i specyfikę płci. Przy każdym ruchu odgrywamy i konstytuujemy naszą płeć, a także naszą nierówność" 29 . Jeżeli mała dziewczynka pragnie przeforsować własne rozwiązanie problemu, przekonać do jakiegoś rodzaju zabawy, wtedy określa się ją jako kłótliwą, jeżeli czyni to chłopiec (nawet w bardzo agresywny sposób) uznaje się, że jest on silny i stanowczy. Kobiety starają się zatem kształtować wzajemne relacje na zasadzie zażyłości i przyjaźni, mężczyźni natomiast bardzo chętnie podkreślają hierarchiczność oraz indywidualizm. Kobietom trudniej zostać dyrektorami czy kierownikami, ponieważ: po pierwsze same uważają, że lepiej sprawdzają się na takim stanowisku mężczyźni, po drugie mężczyźni nie chcą się poddawać „,rządom” kobiety, często je lekceważą. Niestety w niektórych przypadkach atmosfera domu rodzinnego sprzyja osłabianiu motywacji osiągnięć. Wielu rodziców wyraża pogląd, że dziewczynki powinny zapomnieć o rozwoju osobistym a przygotowywać się do roli matki i żony. Jeżeli córki osiągają sukces, najbliżsi, którzy uważają że kariera zawodowa to cecha męska, nie cieszą się z samorealizacji kobiet na polu zawodowym, gdyż jest to niezgodne według nich $\mathrm{z}$ naturą kobiety ${ }^{30}$.

Warto przytoczyć wyniki badania z 1998 roku ${ }^{31}$, które pokazuje jak bardzo społeczeństwo identyfikuje cechy z płcią. Respondentów proszono o przyporządkowanie kilkunastu cech do płci. Okazało się, że wyłącznie kobietom przypisano trzy cechy negatywne (częsta absencja w pracy,

29 D. Tannen, Ty nic nie rozumiesz!, Warszawa 1999, s. 303.

30 Zob. E. Mandal, Pustka na szczycie, „Charaktery” 2003, nr 4.

31 Wptyw procesu prywatyzacji na położenie kobiet: Kobiety polskie w gospodarce okresu transformacji. Raport z badań, Centrum Praw Kobiet we współpracy z Women, Law and Development International z Waszyngtonu (1998 r.), http://temida.free.ngo.pl/spist.htm. 
gadatliwość, posiadanie zobowiązań rodzinnych) oraz trzy pozytywne (atrakcyjność, dobry wygląd, cierpliwość, pracowitość). Poza tym wskazano także na emocjonalność, którą trudno zakwalifikować jako cechę pozytywną czy negatywną. Jeżeli chodzi o mężczyzn, to wyłącznie im przypisano tylko dwie cechy pozytywne: odporność psychiczna i uzdolnienia techniczne. Pozostałe cechy były po równo przydzielone do obu płci. Można zauważyć jednak pewną pozytywną zmianę, gdyż we wcześniejszych badaniach kobietom przypisywano głównie bierność, niezdecydowanie i konfliktowość. Jeżeli chodzi o kłótliwość, to obecnie cecha ta jest dostrzegana u obu płci.

W badaniu opinii publicznej przeprowadzonym przez CBOS $^{32}$ w 1992 roku okazało się, że aż 47\% ankietowanych (kobiet i mężczyzn) preferowało szefa-mężczyznę. Pięć lat później odsetek ten uległ znacznemu obniżeniu (37\%). W badaniu z 1992 roku 34\% osób odpowiedziało, że płeć nie ma dla nich znaczenia, natomiast $\mathrm{w}$ dwóch następnych badaniach znacznie więcej osób zadeklarowało (1998 - 44\%, 2003 - 45\%), że jest dla nich obojętna płeć przełożonego. Praca z kobietą-przełożonym eliminuje wg autorów badań negatywne stereotypy związane z kobietami, natomiast niestety nie implikuje stereotypów pozytywnych. Jednocześnie podkreśla się, że mężczyźni, którzy byli podwładnymi kobiet rzadziej woleliby żeby ich szefem został mężczyzna. Warto podkreślić, że w najnowszych badaniach z 2003 roku zaobserwowano dalszy spadek popularności mężczyzny jako przełożonego, natomiast poglądy kobiet utrzymują się na tym samym poziomie od 1998 roku. Dane przytoczone poniżej pozwalają zaobserwować, jak zmieniały się preferencje odnośnie płci szefa w dziesięcioleciu od wczesnego okresu przemian ustrojowych do teraz.

Według danych GUS-u kobiety stanowią tylko 1/3 wśród menedżerów w Polsce. W badaniu „Menedżerki 2000”33 okazało się, że prezentują one w zarządzaniu cechy zarówno „męskie”, jak i „kobiece”. Okazało się, że większość z nich godzi życie rodzinne z zawodowym - tylko 13\% było pannami, a tylko $1 / 5$ nie miała dzieci. Poza tym aż $45 \%$ było głównymi żywicielami rodziny. Należy zwrócić uwagę jednak na to, że respondentki stanowiły tylko $20 \%$ wśród dyrektorów generalnych i prezesów, były zatrudnione głównie jako wiceprezeski i wicedyrektorki. Nadal wyższe

32 Źródło: Komunikat z badań: Opinie o kobietach pracujacych zawodowo, Warszawa, 2003, komunikat nr 2971, www.cbos.pl.

33 http://www.mfk.org.pl/index.php?d=badania_naukowe\&p=polskie_menedzerki_2000, zob. wyniki badania w „Kobieta i Biznes” 2000, nr 1-2. 
i średnie szczeble zarządzania są zdominowane przez mężczyzn, natomiast na niższych dysproporcja ta się wyrównuje (47\% - kobiety i 53\% mężczyźni).

Tabela 3

Preferencje Polaków związane z płcią przełożonego

\begin{tabular}{|c|c|c|c|c|c|c|c|c|c|}
\hline \multirow{3}{*}{$\begin{array}{l}\text { Czy Pan (i) osobiś- } \\
\text { cie wolał(a)by mieć } \\
\text { w pracy szefa-ko- } \\
\text { bietę czy szefa-mę- } \\
\text { żczyznę? }\end{array}$} & \multicolumn{3}{|c|}{$\begin{array}{l}\text { Wskazania kobiet we- } \\
\text { dług terminów badań }\end{array}$} & \multicolumn{3}{|c|}{$\begin{array}{l}\text { Wskazania mężczyzn we- } \\
\text { dług terminów badań }\end{array}$} & \multicolumn{3}{|c|}{ Ogólem } \\
\hline & $\begin{array}{c}\text { XII } \\
1992 \\
\end{array}$ & $\begin{array}{c}\text { XI } \\
1998 \\
\end{array}$ & $\begin{array}{c}\text { III } \\
2003\end{array}$ & $\begin{array}{c}\text { XII } \\
1992 \\
\end{array}$ & $\begin{array}{c}\text { XI } \\
1998 \\
\end{array}$ & $\begin{array}{c}\text { III } \\
2003\end{array}$ & $\begin{array}{c}\text { XII } \\
1992 \\
\end{array}$ & $\begin{array}{c}\text { XI } \\
1998\end{array}$ & $\begin{array}{c}\text { III } \\
2003\end{array}$ \\
\hline & \multicolumn{9}{|c|}{ w procentach } \\
\hline Kobietę & 14 & 12 & 11 & 11 & 7 & 13 & 13 & 10 & 12 \\
\hline Mężczyznę & 46 & 40 & 40 & 48 & 43 & 33 & 47 & 42 & 37 \\
\hline Wszystko jedno & 33 & 42 & 42 & 36 & 47 & 49 & 34 & 44 & 45 \\
\hline Trudno powiedzieć & 7 & 5 & 7 & 4 & 3 & 5 & 6 & 4 & 6 \\
\hline
\end{tabular}

Źródło: Komunikat z badań: Opinie o kobietach pracujacych zawodowo, Warszawa, 2003, Komunikat nr 2971, www.cbos.pl.

Bardzo popularne staje się pojęcie glass ceiling - szklany sufit (pułap), które oznacza wg OECD nieoficjalne albo nieuznane bariery osobistego awansu w pracy, szczególnie kobiet albo członków mniejszości etnicznych $^{34}$. Podobnie ujmuje to René Redwood, która była kierownikiem wykonawczym w Glass Ceiling Commission ${ }^{35}$ : glass ceiling są sztucznymi barierami, które utrudniają kobietom i mniejszościom możliwość awansu w ciagu ich kariery ${ }^{36}$. W polskich realiach także spróbowano zbadać zjawisko szklanego sufitu oraz sklasyfikować bariery, które „wyrastają” na drodze do samorealizacji zawodowej. Można wyróżnić 3 rodzaje takich barier ${ }^{37}$ :

34 Strona internetowa: School of Industrial and Labor Relations, Cornell University, http://www.ilr.cornell.edu/library/research/QuestionOfTheMonth/archive/glassceiling.html.

35 Komisja federalna powołana w 1991 roku w USA, która pod kierownictwem ministra pracy zajmowała się identyfikacją barier awansu oraz opracowaniem środków zaradczych, szczególnie w odniesieniu do sektora prywatnego.

36 Fragment wystąpienia René Redwood na ,Szczycie kobiet pracujących” zorganizowanym przez Women In Technology International (WITI) - jest to organizacja założona w 1989 roku, która zajmuje się rozwojem kobiet w dziedzinie nauki i techniki, organizuje konferencje regionalne, skupia się zwłaszcza na sferze poszukiwania pracy. Jej siedzibą jest Sherman Oaks (Kalifornia). http://www.inmotionmagazine.com/glass.html.

37 Na podst.: B. Budrowska, Bariery i ograniczenia karier kobiet - wyniki badań nad zjawiskiem ,szklanego sufitu”, w: Płeć a możliwości ekonomiczne w Polsce: czy 
1. Bariery i ograniczenia wewnętrzne: zaniżona samoocena, brak wiary we własne siły, przerażenie związane z szansą zajęcia wyższego stanowiska, brak umiejętności artykulacji problemów; według badania również kobiety, które osiagnęły sukcesy w swej karierze zawodowej przyznają się do wielu lęków, wątpią często we własne kompetencje; kobiety doświadczają dysonansu poznawczego, czyli rozdźwięku między samooceną a wysokimi ocenami działań kobiet formułowanymi przez inne osoby.

2. Przypisywanie kobiet do tradycyjnych ról: kobiety są zmuszone do wybierania między życiem rodzinnym a zawodowym, wiąże się to jednocześnie z postrzeganiem mężczyzny jako mniej obciążonego życiem rodzinnym; nieobecność kobiet na rynku pracy, jak również w sferze nieformalnej (np. wypoczynku) spowodowana jest macierzyństwem oraz obarczeniem licznymi obowiązkami rodzinnymi. Zauważono, że w sferę polityki kobiety wkraczają po „odchowaniu” dzieci, czyli mają opóźniony start w stosunku do mężczyzn, natomiast w firmach jest odwrotnie: kobiety odsuwają moment założenia rodziny czy posiadania dzieci, żeby najpierw zaistnieć na rynku pracy, osiagnąć jakąś pozycję;

3. Bariery zewnętrzne: związane są $z$ dyskryminującymi nastawieniami, postawami, regułami funkcjonowania środowisk zawodowych i politycznych. Wśród tych barier należy wymienić m.in. metody doboru osób na stanowiska wynikające $\mathrm{z}$ faktu homogeniczności elit (kobiety często nie są informowane o tym, ze dane stanowisko się zwalnia; mężczyźni, którzy obsadzają najwyższe stanowiska decydują najczęściej o doborze kadr), mechanizmy solidarności wśród mężczyzn i brak solidarności kobiecej (widoczna jest solidarność męska, wzajemne się wspieranie, natomiast kobiety nie manifestują swej solidarności, a często uważają inne kobiety za złośliwe i zawistne), odmienne standardy ocen pracy kobiet i mężczyzn (kobiety nie mogą pozwolić sobie na błędy, muszą udowadniać, ze są lepsze od mężczyzn ${ }^{38}$, aby utrzymać

kobiety stracily na transformacji?, Dokument Banku Światowego, Departament Walki z Ubóstwem i Zarządzania Gospodarką, Region Europy i Azji Środkowej, s. 70-93.

38 Zob. E. Aronson, T. D. Wilson, R. M. Akert, Psychologia społeczna, s. 671-672. Autorzy piszą: ,Stare powiedzenie mówi, że z powodu dyskryminacji płciowej kobieta musi być dwa razy tak dobra jak mężczyzna, aby uzyskać przewagę". Zaznaczają, że w wyniku analizy wielu badań, stwierdzono, że istnieje niewielka tendencja do oceniania mniej pozytywnie kobiet od mężczyzn, ale nader często występuje dyskryminacja kobiet-szefów. 
swą pozycję, wady mężczyzn natomiast są tolerowane, a ich niezadowalające wyniki w pracy są traktowane $\mathrm{z}$ większą pobłażliwością), stosunek mężczyzn do kobiet w ramach wzajemnej współpracy (np. skłonność do przejmowania przez mężczyzn efektów pracy kobiet, stosowanie wobec kobiet manipulacji, a często okazywanie nieposłuszeństwa kobiecie - szefowi), stereotypowe opinie na temat funkcjonowania kobiet (stosowanie szantażu emocjonalnego, pogląd, że kobiety są bardziej emocjonalne, podkreślanie przez mężczyzn kobiecej delikatności, łagodności, piętnowanie przejmowania cech męskich przez kobiety ${ }^{39}$, przeświadczenie, że kobiety nie są zaradne i przedsiębiorcze, że często plotkują i wykorzystują to, że są kobietami.

Przytoczona powyżej systematyzacja barier ukazuje, że kobiety muszą włożyć wiele wysiłku w budowanie swej pozycji na rynku pracy, że czasami są bezsilne wobec stosowanych wobec nich ograniczeń, a niektóre z barier są zupełnie niezauważane przez przedstawicieli obu płci. Obok szklanego sufitu można także spotkać się z podobnymi pojęciami: „lepka podłoga”, która oznacza, że kobiety są „przylepione” do swej posady, gdyż nie mają możliwości awansu (dotyczy to stanowisk o niskim statusie, jak urzędniczka, sekretarka, pomoc domowa) oraz ,szklanych ruchomych schodów", które w przeciwieństwie do szklanego sufitu stanowiącego barierę dla kobiet, pomagają mężczyznom w zdobywaniu jak najwyższych stanowisk, nawet w zawodach tradycyjnie „kobiecych"40.

Dyskryminacja ze względu na płeć jest stosowana już na etapie rekrutacji do pracy. Pracodawca zadaje często dodatkowe pytania kobietom. Pyta o ich sytuację rodzinna, plany związane z posiadaniem potomstwa, stan cywilny. W publikacjach z zakresu prowadzenia polityki personalnej zaznacza się, że należy unikać różnicowania kandydatów ze względu na płeć. Michael Armstrong ${ }^{41}$ podkreśla, że każda organizacja powinna prowadzić politykę równych szans, która polega na zapewnieniu równych możliwości wszystkim bez względu na stan cywilny, płeć, czy rasę. W procesie rekrutacji i podczas rozmowy kwalifikacyjnej należy m.in. ${ }^{42}$ :

39 Np. jeżeli kobieta jest szybka w działaniu - uważa się ją za niecierpliwą, jeżeli mówi o swoich osiągnięciach - za osobę przechwalającą się, jeżeli przytacza dużo argumentów - gani się jej gadatliwość.

${ }^{40}$ Zob. B. Budrowska, ,, Szklany sufit”, czyli co blokuje kariery kobiet, „Kultura i historia" 2003, nr 6, http:/www.kulturaihistoria.umcs.lublin.pl.

41 M. Armstrong, Zarządzanie zasobami ludzkimi, Kraków 2003, s. 237.

42 Ibidem, s. 688. 
- sporządzić dokładny i aktualny opis stanowiska pracy, który nie dyskryminuje nikogo ze względu na płeć;

- bronić się przed stereotypami związanymi z płcią lub rasą w reklamach i dokumentach rekrutacyjnych;

- unikać pytań dyskryminujących, chociaż podczas rozmowy kwalifikacyjnej można $\mathrm{z}$ kandydatem omówić wszelkie problemy domowe lub osobiste, które mogą mieć wpływ na wykonywanie pracy, o ile tylko nie formułuje się żadnych założeń na podstawie płci kandydata.

W praktyce jednak, mimo zaleceń specjalistów zarządzania zasobami ludzkimi oraz prawnego zakazu ograniczania dostępu do zatrudnienia ze względu na płeć, kobiety w Polsce są nadal dyskryminowane już na etapie starania się o zatrudnienie. Według badań aż w 40\% zakładów kobietom zadaje się pytania, których nie zadaje się mężczyznom. Najczęściej zadawane pytania (według rodzajów działalności organizacji) dotyczą takich zagadnień jak ${ }^{43}$ :

- przemysł - liczba i wiek dzieci oraz możliwości pracy w godzinach nadliczbowych;

- budownictwo - liczba i wiek dzieci oraz ambicje i plany zawodowe;

- transport - wykształcenie;

- bankowość, ubezpieczenia, obsługa nieruchomości i firm - sytuacja rodzinna i plany zmian stanu cywilnego oraz liczba i wiek dzieci;

- usługi (gastronomia, turystyka) - liczba i wiek dzieci oraz ambicje i plany zawodowe;

- handel - ambicje i plany zawodowe oraz możliwości wyjazdów służbowych;

- wydawnictwa, poligrafia - możliwości wyjazdów służbowych oraz sytuacja rodzinna i plany zmiany stanu cywilnego;

- administracja państwowa i wymiar sprawiedliwości - liczba i wiek dzieci;

- inne - możliwość pracy w godzinach nadliczbowych oraz możliwość wyjazdów służbowych.

Pracodawcy obawiają się, że zobowiązania rodzinne kobiet, np. choroba dzieci, spowodują częstą absencję w pracy. Nie chcą również ponosić ryzyka związanego z zajściem kobiety w ciążę (ochrona zatrudnienia kobiet w ciąży). Zdarza się, że osoby rekrutujące pytają, czy kobieta nie jest

43 Wplyw procesu prywatyzacji na położenie kobiet: Kobiety polskie w gospodarce okresu transformacji. Raport ..., op. cit. 
w ciąży, a nawet żądają zaświadczeń lekarskich ${ }^{44}$. Ogłoszenia o pracę zawierają często określenie płci kandydata, formułując bezpośrednio wymagania (np. młodego Pana na magazyn, dyspozycyjną Panią do biura), bądź też pośrednio - używając żeńskiej bądź męskiej formy (szefa działu logistyki, sekretarkę/asystentkę prezesa).

Kolejnym polem, na którym są dyskryminowane kobiety jest poziom wynagrodzeń. Ekonomiczne badania nad dyskryminacją ${ }^{45}$ zapoczątkował Gary Becker. Stworzył on m.in. ${ }^{46}$ model dyskryminacji. Według niego kobiety i mężczyźni mają równe szanse na zatrudnienie, jednak kobiety są wynagradzane poniżej swojej produkcyjności. Niższa płaca dla kobiet opiera się na subiektywnej ocenie pracodawcy co do kosztów zatrudnienia kobiet. Becker zaznacza, że wyrównanie płac nastąpi automatycznie, że po pewnym czasie niedyskryminujący pracodawcy nie będą mogli już konkurować z dyskryminującymi. Sprzeciwia się podejmowaniu działań zmniejszających dyskryminację, gdyż mogłoby to powodować przyjmowanie do pracy mało wydajnych osób, a i tak owe działania nie zmniejszą dyskryminacji. Autorka drugiego modelu - Asa Rosen podkreśla, że kobiety nie mają równych szans przy zatrudnianiu. Pracodawcy kierują do nich mniej ofert pracy, a kobiety tym samym przyjmują te oferty, które są „gorsze” pod względem płacy i dostosowania stanowiska do wydajności pracownika. Zaznaczyła, że dyskryminacyjna równowaga jest stabilna, więc należy podjąć szereg działań, aby osiągnąć zrównanie pozycji kobiet i mężczyzn. Należy podjąć owe działania, ponieważ doprowadzą one do zwiększenia efektywności ekonomicznej poprzez lepsze dopasowanie umiejętności pracowników do stanowisk (często np. kobieta jest bardziej wydajna na danym stanowisku, a nie oferuje się jej go).

Polskie kobiety zarabiają dużo mniej niż mężczyźni na tych samych stanowiskach. W październiku 2002 roku mężczyźni zarabiali średnio o 8,8\% powyżej, a kobiety aż o 16,9\% poniżej średniej krajowej. Przecięt-

44 B. Budrowska, Bariery i ograniczenia karier kobiet - wyniki badań nad zjawiskiem ,,szklanego sufitu”, w: Pteć a możliwości ekonomiczne w Polsce: czy kobiety stracity na transformacji?, Dokument Banku Światowego, Departament Walki z Ubóstwem i Zarządzania Gospodarką, Region Europy i Azji Środkowej, s. 27.

45 Na podst. A. G. Dijikstra, J. Platenga, Ekonomia a płeć, Gdańsk 2003, s. 52-57.

46 Amerykański laureat nagrody Nobla, zajmował się także podziałem pracy w rodzinie oraz kapitałem ludzkim. Rozważania na temat dyskryminacji przedstawił m.in. w książce: The economics of discrimination zob. też strona internetowa G. Beckera: http://home.uchicago.edu/ gbecker/index.html. 
ne wynagrodzenie kobiet było zatem o $17 \%$ niższe niż przeciętne wynagrodzenie mężczyzn.

Wykres 4. Wynagrodzenie miesięczne brutto według płci i grup zawodowych w październiku $2002 \mathrm{r}$.

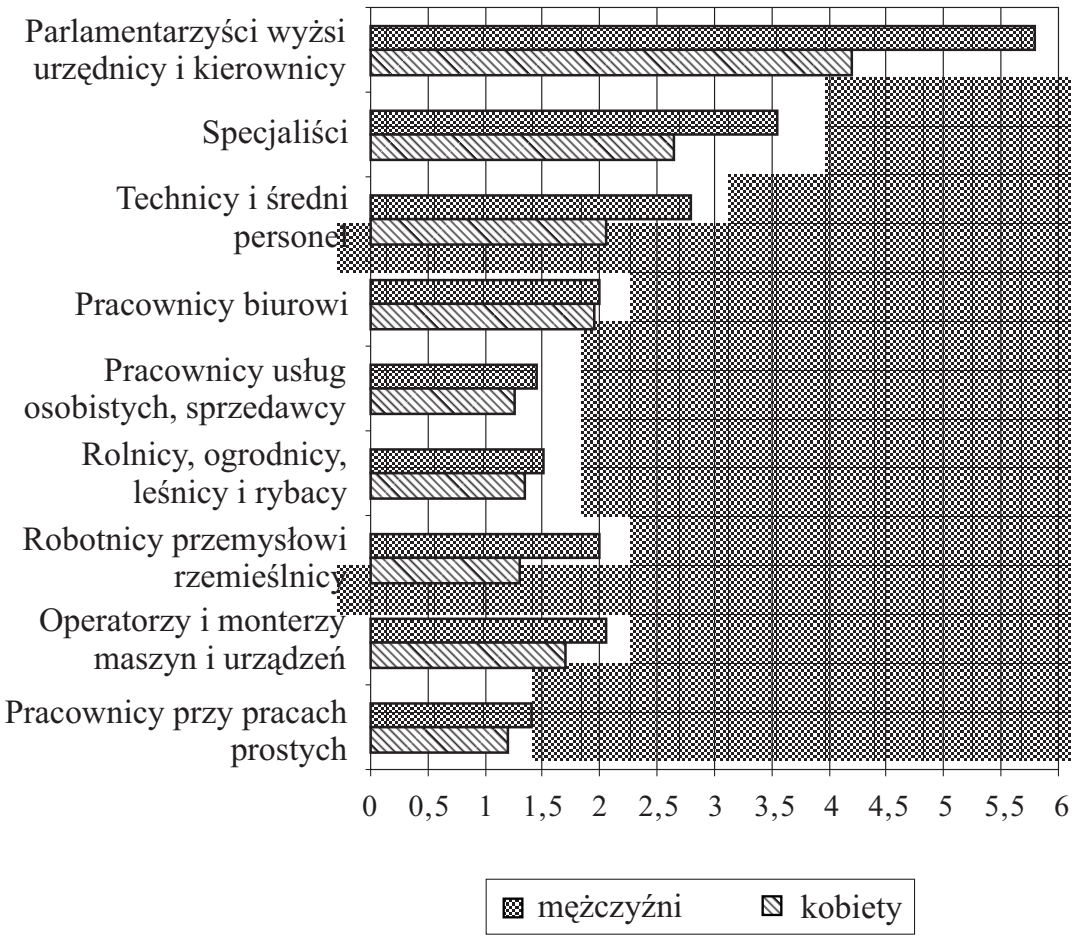

Źródło: GUS, Kobiety i mężczyźni na rynku pracy, http://www.stat.gov.pl/dane_spol-gosp/praca_ludnosc/kob_mez_praca/index.htm.

Z danych GUS-u z 2001 roku wynika, że największa rozbieżność między kobietami i mężczyznami występuje na najwyższych szczeblach kariery oraz stanowiskach specjalistycznych, najmniejsza natomiast przy pracach niewymagających szczególnych kwalifikacji, czyli przy tzw. pracach prostych. Zwrócić należy uwagę, że generalnie różnica w wynagrodzeniach kobiet i mężczyzn tak samo wykształconych jest większa w sektorze publicznym niż w sektorze prywatnym. Przeciętne wynagrodzenie kobiet w 2001 roku stanowiło w sektorze publicznym - 78,6\% 
i prywatnym - 83,6\% przeciętnego wynagrodzenia mężczyzn. Niepokoi zwłaszcza fakt, że kobiety z wyższym wykształceniem zarabiają tylko około $74 \%$ (sektor publiczny $-74,3 \%$, sektor prywatny $-74,9 \%$ ) tego, co mężczyźni. „W obu sektorach własności duże firmy lepiej wynagradzają pracowników: im większa firma, tym większe przeciętnie wynagrodzenie, przy czym tendencja ta dotyczy i kobiet i mężczyzn. Generalnie we wszystkich wyodrębnionych w statystyce kategoriach firm według liczby pracujących przeciętne wynagrodzenia brutto kobiet są niższe od przeciętnych wynagrodzeń mężczyzn. Najmniejsze różnice między wynagrodzeniami kobiet i mężczyzn występują w firmach najmniejszych i dotyczy to zarówno sektora prywatnego jak i publicznego. Natomiast największe różnice między wynagrodzeniami kobiet i mężczyzn występują w firmach największych w obu sektorach"47.

Tabela 4

Zarobki kobiet w zależności od poziomu wykształcenia i rodzaju własności sektora

\begin{tabular}{||l|c|c||}
\hline \multirow{2}{*}{ Poziom wyksztalcenia } & \multicolumn{2}{|c||}{ Wskaźnik zarobków kobiety/mężczyźni } \\
\cline { 2 - 3 } & sektor publiczny & sektor prywatny \\
\hline Wyższe & 74,3 & 74,9 \\
\hline Policealne & 77,1 & 85,5 \\
\hline Średnie zawodowe & 76,0 & 81,3 \\
\hline Średnie ogólne & 87,0 & 82,0 \\
\hline Zawodowe & 61,9 & 73,9 \\
\hline Podstawowe i niższe & 63,9 & 79,5 \\
\hline
\end{tabular}

Źródło: GUS, październik 2001, podaję za: B. Budrowska, Bariery i ograniczenia karier kobietwyniki badań nad zjawiskiem , szklanego sufitu”, w: Płeć a możliwości ekonomiczne w Polsce: czy kobiety stracity na transformacji?, Dokument Banku Światowego, Departament Walki z Ubóstwem i Zarządzania Gospodarką, Region Europy i Azji Środkowej, s. 70-93.

Różnice w zarobkach kobiet można tłumaczyć zarówno wyżej opisanymi modelami Beckera, jak i Rosen, ale należy również pamiętać o teorii kapitału ludzkiego, teorii segregacyjnej i podejściu instytucjonalnym. Pierwsza z tych teorii była bardzo popularna w latach 70 -tych i 80 -tych XX wieku i podkreślała rolę wykształcenia przedstawicieli obu płci, na-

47 B. Budrowska, Bariery i ograniczenia karier kobiet - wyniki badań nad zjawiskiem ,,szklanego sufitu”, w: Pteć a możliwości ekonomiczne w Polsce: czy kobiety stracity na transformacji?, Dokument Banku Światowego, Departament Walki z Ubóstwem i Zarządzania Gospodarką, Region Europy i Azji Środkowej, s. 23. 
stępnie zaczęto zwracać uwagę na nierównomierne rozmieszczanie kobiet i mężczyzn w zawodach i na stanowiskach (segregacja), a pod koniec lat 80-tych badano czynniki determinujące wysokość płacy. Główne założenia odnoszące się do dysproporcji w wynagrodzeniach ze względu na płeć prezentuje tabela 5 .

Tabela 5

Różnice w zarobkach między kobietami a mężczyznami w ujęciach teoretycznych

\begin{tabular}{|c|c|c|}
\hline Teoria kapitału ludzkiego & Teoria segregacyjna & Podejście instytucjonalne \\
\hline $\begin{array}{l}\text { Kobiety nie inwestująw swoje } \\
\text { wykształcenie, co powoduje } \\
\text { zmniejszenie ich wydajności. } \\
\text { Pracodawcy są przekonani, } \\
\text { że nie warto opłacać kobie- } \\
\text { tom kursów doszkalających, } \\
\text { gdyż będą one musiały zrezy- } \\
\text { gnować na pewien czas z ka- } \\
\text { riery zawodowej. Kobiety } \\
\text { mają więc ograniczone mo- } \\
\text { żliwości podnoszenia kwali- } \\
\text { fikacji, co wpływa na to, że są } \\
\text { one mniej wydajne niż męż- } \\
\text { czyźni. }\end{array}$ & $\begin{array}{l}\text { Według badaczy czynniki } \\
\text { związane z wykształceniem } \\
\text { stanowią tylko w } 50 \% \text { o tym, } \\
\text { czy kobieta ma niższe wyna- } \\
\text { grodzenie. Wskazywano, że ze } \\
\text { względu na istnienie horyzon- } \\
\text { talnej (zawody męskie i żeń- } \\
\text { skie) i wertykalnej (hierarchi- } \\
\text { cznej) segregacji kobiety są } \\
\text { przydzielane do zawodów } \\
\text { i stanowisk, w których są niż- } \\
\text { sze płace. }\end{array}$ & $\begin{array}{l}\text { Próbuje udzielić odpowiedzi } \\
\text { na pytanie: dlaczego prace } \\
\text { wykonywane głównie przez } \\
\text { kobiety systematycznie są } \\
\text { niżej wynagradzane niż prace } \\
\text { wykonywane przez mężczyzn? } \\
\text { Poszukiwanie czynników de- } \\
\text { terminujących wysokość płacy, } \\
\text { np. wyłączenie postanowień } \\
\text { dotyczących wynagrodzeń } \\
\text { pracownic ze zbiorowych } \\
\text { umów o pracę. }\end{array}$ \\
\hline
\end{tabular}

Źródło: Opracowanie własne na podst.: A. G. Dijikstra, J. Platenga, Ekonomia a płeć, Gdańskie Wydawnictwo Psychologiczne, Gdańsk 2003, s. 52-57.

Należy podkreślić, że wykształcenie kobiet systematycznie rośnie. Już teraz są one lepiej wykształcone niż mężczyźni, a mimo to stanowią większą część wśród bezrobotnych (również długookresowo), a także rzadziej dostają awanse i możliwości szkoleń. Polskie kobiety walczą o zrównanie swoich szans na rynku pracy, tym bardziej, że coraz więcej z nich samodzielnie się utrzymuje i wychowuje dzieci. Niestety wiele z kobiet nie uświadamia sobie istniejących barier, a często same kobiety mają tendencję do zaniżania swej wartości. Większość społeczeństwa uważa, że sytuacja kobiet jest problemem ważnym, jednak podczas badania CBOS-u wielu respondentów odpowiedziało, że nie spotkała się ze zjawiskiem dyskryminacji. Prawie trzy piąte kobiet (59\%) i dwie trzecie mężczyzn (66\%) nie zetknęło się z tym zjawiskiem ${ }^{48}$. Jak wynika z powyż-

48 CBOS, Opinie o prawnych gwarancjach równości ptci, 1999, Komunikat nr 2244, www.cbos.pl. 
szych rozważań na pewno nie wystarczają prawne gwarancje równości, należy także podejmować działania na rzecz walki ze stereotypami. Pozostaje mieć nadzieję, że stopniowo wzorem niektórych koncernów międzynarodowych i większych firm polskich pracodawcy zaczną dostrzegać w kobietach pracowników równych mężczyznom, których wydajność wcale nie spada w momencie urodzenia dziecka, a wystarczy tylko stworzyć im dobre warunki, by odwdzięczyły się firmie lojalnością i bardziej wytężona pracą. Przedsiębiorstwa, które zwyciężają w rankingach na firmę przyjazną matkom wprowadzają różne udogodnienia, np. pozwalają na elastyczny czas pracy, dofinansowują wynajęcie niani, pozwalają część pracy wykonywać w domu i utrzymywać kontakt z miejscem pracy przez internet, tworzą firmowe przedszkola. Dużą szansę stwarza możliwość wykorzystania środków unijnych z programu Equal, który jest finansowany ze środków Europejskiego Funduszu Społecznego i ma pomagać w tworzeniu lepszych miejsc pracy przy zastosowaniu innowacyjnych metod, jak również powinien rozwiązywać problem dyskryminacji na rynku pracy.

Ostatnio przez kraj przetoczyła się dyskusja o wprowadzeniu tzw. „,becikowego". Liga Polskich Rodzin pragnie natomiast stopniowej likwidacji przedszkoli i wprowadzania zasiłków wychowawczych w wysokości 200 zł. Działania te mają zachęcać kobiety do rodzenia dzieci, jak również do poświęcania się ich wychowywaniu i rezygnacji na pewien czas z pracy. Powstaje pytanie: dlaczego Polska wzorem zachodnich państw nie stawia na działania długookresowe, które pozwolą się realizować kobietom równocześnie w pracy zawodowej i w opiece nad dziećmi? Krótkookresowe instrumenty mają być, według zapewnień polityków, elementami tworzonej polityki prorodzinnej. Pozostaje zakończyć refleksja, że w USA, aby jak najbardziej pomóc kobietom i likwidować nawet niewidzialne bariery ich awansu, powstała Komisja ds. Szklanego Sufitu, w Polsce natomiast, gdzie skuteczna walka z przeszkodami uniemożliwiającymi efektywne funkcjonowanie kobiet na rynku pracy jest dopiero w stadium zalążkowym, zlikwidowano czwartego listopada 2005 roku stanowisko pełnomocnika rządu ds. równego statusu kobiet i mężczyzn (premier Kazimierz Marcinkiewicz odwołał Magdalenę Środę), a zakres zadań tego urzędu przekazano do Ministerstwa Pracy i Polityki Społecznej. 


\section{Summary}

Polish women are in a significantly less advantageous position than men with respect to employment, or professional promotion. They are also the majority among the unemployed, despite their increasingly better education. The unequal attitude to women is also expressed in terms of their salaries - on average women earn $17 \%$ less than men. The paper presents the statistical data on women's unemployment, describes the legal conditions of women's functioning on the labor market, and shows that, despite the formal ban on discrimination, it is present in more or less concealed forms. The paper describes the obstacles women face trying to find employment and in taking full advantage of their skills, e.g. the glass ceiling. The author familiarizes the notion of the glass ceiling and she also refers to the role of stereotypes and the atmosphere of one's home in the future functioning on the labor market. 